\section{Crowdfunding as an Alternative for Developing Investigative \\ Journalism: A baseline analysis of the education sector in Portugal \\ Crowdfunding como alternativa \\ para el desarrollo del periodismo de \\ investigación: análisis del sector \\ educativo en Portugal}

DOI: https://doi.org/10.32870/cys.v2019i0.7374
MARIA JOSÉ PALMA

LAMPREIA DOS SANTOS 1

https://orcid.org/0000-0002-1992-0419

NAWAZ AHMAD 2

https://orcid.org/0000-0002-6029-7868

The subprime crisis from 2007 and the availability of free news on the Internet led to a drastic decrease of investigative journalism in Portugal. Crowdfunding could be an alternative to traditional models of financing investigative journalism. The present paper aims to analyze the crowdfunding for financing investigative journalism in that country. The methodology used is exploratory. The main results highlight confirm the low entrepreneurial skills of journalists. We suggest the future inclusion of courses in economics and entrepreneurship in the academic degrees in Portugal to overcome this problem.

KEYWORDS: Investigative journalism, education, entrepreneurship, financing, crowdfunding.

La crisis de alto riesgo a partir de 2007 y la disponibilidad de noticias gratuitas en Internet llevaron a una disminución drástica del periodismo de investigación en Portugal. El crowdfunding podría ser una alternativa a los modelos tradicionales de financiamiento del periodismo de investigación. El presente trabajo tiene como objetivo analizar el uso del crowdfunding para financiar el periodismo de investigación en ese país. La metodología utilizada es exploratoria. Los principales resultados confirman las bajas habilidades empresariales de los periodistas. Sugerimos la inclusión futura de disciplinas en economía y emprendimiento en los grados académicos en Portugal para superar este problema.

PALABRAS CLAVE: Periodismo de investigación, Educación, Emprendimiento, Financiación, Crowdfunding.

How to cite:

Dos Santos, M. J. \& Ahmad, N. (2019). Crowdfunding as an Alternative for Developing Investigative Journalism: A baseline analysis of education sector in Portugal. Comunicación y Sociedad, e7374.

DOI: https://doi.org/10.32870/cys.v2019i0.7374

1 University of Lisbon, Portugal.

mjpls1963@gmail.com

2 Institute of Business Management, Pakistan.

nawaz.ahmad@iobm.edu.pk

Submitted: 25/01/19. Accepted: 02/09/19. Published: 06/11/19. 


\section{INTRODUCTION}

The crisis that befell journalism in general and the Portuguese in particular, following the economic and financial crisis of subprime beginning in the United States of America (USA) after 2007 and reflected in the European economies in general and in Portugal in particular, led to a reduction of costs in newsrooms of newspapers resulting in fewer journalists, who in turn are responsible for a greater number and diversity of news.

In order to overcome the impacts of the financial economic crisis, considerable efforts have been made to increase education and training student population in order to improve their skill levels, to become more competitive on an increasingly globalized and demanding market. Thus, gradually, the levels of education and training of the Portuguese population have been increasing. So, we are facing more informed citizens. This conducts to the need for a new paradigm with regard to funding models of the production of news, in order to contribute to a more informed and more qualified personnel applied to journalistic projects in pursuit of one of journalism's goals, to ensure the investigation and subsequent public access to specific topics of interest and not merely submitted to the media agenda.

But the traditional model of newspapers is based on a specific environment that no longer exists (Carvajal, García-Avilés \& González, 2012). Furthermore, the increase of applications to read news on mobile platforms, which have increased competition and sped up survival strategies. The digital market is a constant and unstoppable evolution that increases the distance to traditional media. The news became a commodity at zero cost. Any user can access online content for free with lower production costs (Carvajal et al., 2012) which also helps that today's editors strive to find a sustainable business model to finance their newspapers and the workforce they need. At the same time, revenues from online advertising are insufficient to offset the dwindling revenues of the press, and it is, therefore, essential to reducing costs. Thus, degitalisation took over the conventional printing advertising market and its volume was greatly reduced. The digital 
platforms are accessible free of cost therefore news are available against no cost to the masses which resulted in reduced revenue, subsequently lesser funds are available to finance quality investigative journalism as it needs sufficient funds. Besides that, Gómez-Rodríguez, MéndezPupo and Cortés-Lozano (2015) refer: "Although the economic crisis and digital convergence have affected the vast majority of the media, in the Guadalajara Metropolitan Area new newspapers have appeared in tabloid printed format in recent year" (p. 211). This is a recent trend of fake news and disinformation.

According to Gómez-Rodríguez \& Gallo-Estrada (2016), we are in a phase of transition and experimentation, as well as a confirmation of new cultural practices of consumption and production of contents of books, newspapers and journals of all kinds, and no one can know for sure if the aforementioned products will disappear in its paper format.

Against this backdrop, many questions arise: 1) What will be the solution for the economically sustainable model of digital investigative journalism?; 2) Are non-profit organizations the only viable path for journalism in the public interest?; 3) What is the role of collaborative funding in this process with the support of social networks?; 4) Are the Portuguese journalists and their readers prepared for this challenge?

According to Gómez-Rodríguez, Morrell and Gallo-Estrada (2017), few research studies in have incorporated novel forms of analyzing the field in view of the current media ecosystem. The authors affirm:

We believe that this will be transformed as the researchers trained in the use of other methodologies to study the new media and phenomena, and when the research is enriched with collaborative work with researchers from other non-social or humanistic areas (pp. 35-36).

The crowdfunding (collaborative funding) proves to be an option for funding investigative journalism and can overcome these constraints. At the same time, users can suggest topics of interest, which they believe deserve attention and journalistic investigation, and this process can provide a solution to a major gap in the current journalism (Carvajal 
et al., 2012). On the other hand, one most prominent functions of journalism are to give voice to those who do not have it. It has always served to give visibility to situations and people that otherwise would lack it.

The present paper aims to analyze a new alternative for financing the Portuguese investigative journalism which is already widely used in other countries: the crowdfunding, in order to infer its potential in financing it. So, we contextualize the crowdfunding in general and applied to journalism in particular, analyze their background and other alternative forms of financing the investigative journalism and the intrinsic motivation of crowdfunding and finally we analyze the case study of a Portuguese platform dedicated to investigative journalistic projects, in order to infer the future potential development and paths and how to overcome their remaining limitations with regard to curricular limitations of current journalism courses.

\section{METHODOLOGY}

The methodology used is exploratory and includes: 1) A systematized bibliographic review, namely, mainly actualized SCOPUS or Web of Science (WoS) papers. For this purpose, SCOPUS and WoS databases were consulted from January 6th, 2019 to July 30th, 2019. The search included the terms "crowdfunding", "journalism", "theories of communication", "theories of education", "investigative journalism in Portugal", among others correlated terms with the subject. This research was done in Portuguese and in English languages; 2) The websites and social media mention of the crowdfunding platforms were analyzed both in Portugal and in the text, always looking for references to communication and journalism (from March 5th, to July 15th 2019); 3) An interview was conducted with the manager of the crowdfunding platform I Fund News (Carvalhão, personal communication, 2019), in Portugal on March 15th, 2019; 4) All the undergraduate, masters and doctoral courses in Portugal and their references to the economics course unit were finally analyzed from University sites and from the Ministry of Science, Technology and Higher Education [MCTES] (2019) and DGES. 


\section{BACKGROUND AND DEVELOPMENT OF CROWDFUNDING}

The economy of sharing or collaborative funding in journalism appears with Spot.us, which is a community-based platform for journalists in California, created in 2006 by David Cohn (Carvajal et al., 2012). However, the origin of crowdfunding term results of their adaptation to another concept that was in the past announced as a precursor of the death of journalism: the crowdsourcing. In this context, it was believed that each user could be a journalist. Nowadays, there are only a few examples of collaborative meagre and not substitutive.

Crowdfunding occurs when a company driven by profit outsources essential tasks specific to the production or sale of your product to the general public in the form of call (open call) on the Internet, with the intention of motivating people to make a voluntary contribution for the production process of free enterprise and significantly lower than the contributors to represent the company (Kleemann, Voss \& Rieder, 2008). This means that companies create value using consumers as volunteers and almost free labour force. The latter authors as well as Lawton and Marom (2010) and Carvajal et al. (2012) identify Web 2.0 as a prerequisite for the development of crowdsourcing and argue that without this structure it would be unlikely for companies to be able to easily reach these consumer networks. Thus Web 2.0 is defined from various points of view, technology is based on computers capable of processing information, which means that it can be spread more easily and recombined in other formats. Sociologically, Web 2.0 is the beginning of the creation of networks of individuals who share common interests. From an economic point of view, it features the ability for anyone to create content and place it on the network. These features generate an abundance of information that comes up against a lack of attention from consumers, unable to cope with all the available information.

The crowdfunding is defined as the finance-related process by which projects or businesses use the web to request and receive funds from the crowd in the form of monetary donations, sometimes in exchange for a future product, service or reward (Belleflamme, Lambert \& Schwienbacher, 2011 ; Kleemann et al., 2008) . The Internet and the 
social networks are by nature in the centre of these concepts because the entire process is performed. At the general level, the crowdfunding aims to attract the public to finance small projects unlikely to be funded through traditional financial systems, using social networks like Twitter or Facebook (Gerber, Hui \& Kuo, 2012). The first crowdfunding platforms appeared more than a decade ago as a community tool of distribution, and its development is directly related to the progress of Web applications and mobile network services. Entrepreneurs and businesses can use the crowd to get ideas, raise money, and solicit opinions about the product, creating an overall supportive environment and collective decision-making by allowing businesses to connect to potential customers (De Buysere, Gajda, Klevelaman \& Marom, 2012).

The appearance of Kickstarter in 2009 was the first step for creating a targeted only creative projects platform, aimed at financing through a model "all or nothing", where the creator of the project can only validate it by achieving a target proposed at the launch of the crowdfunding campaign, a model that is now common to a diverse number of projects. The simplicity of crowdfunding is one of the secrets of the success of this platform, as well as the rules established for the operation of the funding process. All projects in the platform must be inserted in the creative arts, there cannot be solidarity initiatives, and the applicants have to declare the amount that the project needs to achieve and the respective end date. If the projects do not reach the expected amount in the stipulated time period, all donations are returned to lenders (Steiberg \& DeMaria, 2012).

Since then various international crowdfunding platforms have emerged and expanded in different areas and fields such as IndieGoGo and RocketHub, which are also used to finance similar projects. However, they selected a different funding model, in which the creator can get finance to a project that have not yet reached the target. For this purpose, the crowdfunding platforms provide a space of encounter between creators and funders to exchange resources in order to give substance to the ideas (Howe, 2008; Schwienbacher \& Larralde, 2010; Steinberg \& DeMaria, 2012). The online platform thus receives applications from creators who wish to expose their business, idea or cause. Some platforms do a pre-selection of ideas based on their own 
criteria while others automatically publish all projects. In the first case, the selection typically is based on experience, design and feasibility. Then the idea is accepted on the platform, and the designer's task is to make a presentation, which often takes the form of video, but can also be described in text and image for a certain period of time and financial purpose, so to captivate potential lenders. Usually, the creators use social networks to reach potential lenders on a larger scale. Then the financiers support the idea, through financial donations, directly through the crowdfunding platform. During the fundraising campaign, the creator keeps updates on the course of the project from the same platform. After the initial investment, many lenders choose to remain involved in the decision-making and overall strategy of the project and, in many cases, communication between the two sides continues as the project progresses through the online platform (Agrawal, Catalini \& Goldfarb, 2011, 2013; Mollick, 2014).

With regard to newspaper projects, Spot.us is the first and most famous international crowdfunding platform since 2006. This site has operated as a community where freelancers and journalists obtain donations from users. Journalists present their work to the users or display a subject on which they would like to get a journalistic investigation. While journalists hope to obtain funding as their work takes shape, trust lenders in the response of journalists, that the work will be delivered. If the tasks are successful, traditional media can then buy the stories and publish them. Otherwise, they are only posted on the site. This relationship stems from the platform, promoting transparency and becoming possible through donations from financiers (Schwienbacher \& Larralde, 2010).

\section{THEORETICAL FRAMEWORK AND COMMUNICATION THEORIES}

Contemporary research has shown how media companies around the world face a shrinking advertising base, fragmenting audiences and rising competition from mobile, social, and digital media (Anderson, Bell \& Shirky, 2015; Lewis \& Westlund, 2015). That is an economic problem of sustainability to the media industries in the future. According 
to Albarran (2016) media economics is "the study of how media industries use scarce resources to produce content that is distributed among consumers in a society to satisfy various wants and needs" (p. 18) covering the range of managerial strategies and tactics associated with media organizations and industries.

Also, various authors refer the need for media companies to innovate (Du, Yalcinkaya \& Bstieler, 2016; Lewis \& Westlund, 2015). Among these strategies for innovation and solving an economic problem, Lewis and Westlund (2015) present big data as an opportunity for value creation through revised business processes as well as new products and services. According to these authors big data has obvious relevance for business-side revenue opportunities, allowing media companies to better understand and serve particular audiences and advertisers and allowing media economic efficiency. But also presents risks, namely, accentuate the problem of job insecurity and customize news and publicity according to readers' preferences.

As a consequence, the new digital era also brings new developments in the theories of communication (Martín-Serrano, 2019). The Theory of Ideology asserts that "mass communication" kept the market economy functioning. And that hacks it creating "false" needs (Freitas, Silva \& Amante, 2017).

Theories of communication, mainly the Signalling Theory, has often been employed to understand crowdfunding (Parhankangas \& Renko, 2017). Many of these studies have focused on identifying signals facilitating fundraising, such as human and social capital of the entrepreneur, as well as quality of the product (Anglin et al., 2018).

\section{THE MOTIVATIONS FOR PARTICIPATION AND}

\section{FINANCING CROWDFUNDING}

According to Kleemann et al. (2008), the participants of crowdsourcing projects, the precursor of crowdfunding, have intrinsic and extrinsic motivations. The first is moved by the pleasure or fun to perform certain tasks, while extrinsic motivations relate to an external reward such as money, goods, employment benefits, learning, recognition or even a certain degree of dissatisfaction with current products. 
Gerber et al. (2011) and Agrawal et al. (2013) conclude that crowdfunding's participants are motivated to participate in social interactions provided by platforms, in particular, strengthen the commitment to an idea through feedback to the creators or, in the case of lenders, the feelings of attachment to a community with similar interests and ideas. For the creators, there are two main reasons that include a lower cost of capital and easier access to more information as well as important related motivations, with the feedback we can get from the lenders.

As for lenders, motivations involve five different aspects, namely, access to investment opportunities, participation in community support for a product, service or ideas playing philanthropy a surprisingly significant role in most crowdfunding platforms and the formalization contracts (Agrawal et al., 2013). Aitamurto (2011) concludes that the primary motivation of donors is to contribute to the common good and social change. Thus, they are also promoters of investigative journalism.

So far, motivation for evolving such crowdfunding platforms is a concern, its simple, that is, to bring and fund quality projects and to optimize profits. This requires attracting an extensive community of funders and design the market to attract high-quality projects, reduce fraud and facilitate an effective meeting between ideas and capital. The crowdfunding platforms also have the incentive to attract projects that can reach great attention from the media, because that way they can expand existing community lenders, allowing the platform to expand into new categories (Agrawal et al., 2013). Some disadvantages to this model are the risk of creators transmitting too much information about their product, idea or service as well as on the side of financiers, the possibility of fraud, the incompetence of the creator or the own risk of the project. According to Agrawal et al. (2013), these problems can generate a fault in this market, which can occur for a variety of causes resulting in a less transparent relationship between creators and financiers, or even a bad evaluation from the financiers.

De Buysere et al. (2012) consider that the motivations that lead users to fund certain projects include social, material or financial return. In the first case, the lenders are satisfied to learn and cope with the 
project. That intrinsic motivation occurs primarily in projects that rely on donations and non-profit organizations. In the case of a financial return, the lender can simulate marketing research through the feedback given by users.

\section{THE FINANCING PROCESS OF CROWDFUNDING}

From a financial point of view, crowdfunding can be defined as the collective cooperation of individuals who apply their money in a project or product. From an economic point of view, it provides a better matching of supply and demand, resulting in a more efficient production process (Belleflammea et al., 2010).

In the financial perspective of individuals who launch and fund projects on the platforms, breeders try to create value for people who support them, according to the founders of the largest platforms. Although it is not a donation, crowdfunding is not an investment. The relationship between creators and financiers is new and is deeply related to the savings of social networks. Lenders always get something in exchange for projects that they support, each of which receive rewards in return for the donations they make, but the financiers are not investors, in the sense that they usually do not get financial benefits or shareholding opportunities (Barabas, 2012).

Compared with the support of financial services, the main difference lies in the financier participating in crowdfunding creating an entrepreneurial aspect associated with their enthusiasm, understanding the potential of the project and having the intrinsic need to become a part of the group that will "make it happen". Often, the lender does not have sufficient resources to fund an entire project or for the same range of skills that can be found in specialist venture capital company. However, the lender usually identifies himself with the project, is open to change and is pleased to help to add a social nature to the project (De Buysere et al., 2012). Schwienbacher and Larralde (2010) argue that a crowd can often be more efficient than a single individual or even a team to solve certain business problems. According to these authors, the risk assumed by each investor is also lower, not only because each 
individual contributes with an inferior value, but also because the transferring crowd becomes a potential consumer of the product or service in question in addition to an extra incentive to disclose, once it reaches the market.

So far, profit maximization has been a rare goal in crowdfunding. At the same time, the risk of failure does not necessarily translate into the risk of capital loss, because success in the financing is not normally defined through the financial return (De Buysere et al., 2012). These authors and Agrawal et al. (2011, 2013), Mollick (2014) and Rivera (2012) propose an exhaustive classification in twelve different models of funding, crowdfunding revealing a variety of options whose potential increases the more they are combined together: donations, rewards,presales, loans, social loans, peer-to-peer lending (private), peer-tobusiness loan, equity, profit sharing, reward in kind, financing in kind, and hybrid models, in addition to donations and rewards. In the latter two models, the biggest motivation of donors is social, intrinsic, which is usually a good basis for a long-term relationship. Loans are another form of financing crowdfunding when a company borrows money from a group of people instead of making a financial institution.

\section{THE DEVELOPMENT OF CROWDFUNDING IN PORTUGAL}

In Portugal, the first generalist crowdfunding platforms appeared in 2011, offering a service similar to the American Kickstarter. With regard to specific platforms for journalistic projects, there are only two in Portugal: I Fund News and TKNT (television that is not television.

The latest data published on crowdfunding for the Portuguese case, on all platforms either general or journalistic projects, suggest a level of transactions in the order of one million euros, as long as they have emerged in Portugal. Although its value is still low, especially, compared with the US market, the trend is increasing. These values are only estimative so there is no data from official statistics, so it is based on the sum of the different values of existing platforms in Portugal. The PPL rate of success from projects is around 49\% and was raised up to more than 500 thousand euros, enough to support 170 projects. 
The Massivemov platform raised since 2011 a total of 103500 euros, with a $52 \%$ success rate, having financed 33 projects. The average value of support stands at 33 euros in the case of PPL and 46 euros in Massivemov platform.

\section{The Portuguese journalism research and the platform I Fund News}

Freitas, Silva and Amante (2017) analyze investigative journalism and characterize its professionals in Portugal. The main results of these authors confirm that the functions, profile and conditions under which the investigate journalists work are different and diverse from traditional journalism. They confirm that investigative journalism practices in Portugal are recognized as being of high quality. The conditions of work assume different characteristics from those that occurred in the period before the 21 st century, due to economic constraints and the dictatorship of the time available for research (immediate). Although Portugal has been a democratic regime since 1974, Coelho \& Silva (2018) referx to the "screamingly biased character of the cream of national commentary" (p. 85); repeating each other, journalists who specialize in economics and politics rolled "at the sound of the waltz of governance" (p. 85).

This attitude of specialized journalism divert journalists from their core investigation mode to the power table, where they struggle for more power, according to Coelho \& Silva (2017).

In order to analyze the I Fund News platform, we used the case study methodology, analyzing since its inception, through all the primary and secondary references, media reports, interviews with the manager of the platform (Carvalhão, personal communication, 2015) and informal interviews to journalists, and experts throughout the process.

Although it was launched in November 2013, the I Fund News platform appeared immediately on news in various online and traditional media, from magazines to TV, from the online editions of newspapers to specialized blogs. Moreover, several journalists were contacted assets, the press and television, and on the other hand, contacted all the country's universities with journalism courses through a "press tour", an action that aimed to "knock door to door and go directly to potentially 
interested people" (Carvalhão, personal communication, 2015). A Facebook page was also created and it is still maintained. During about six months the platform had a team with two staff members allocated to the project at a full-time base from the Edge Innovation company which manages the platform.

Nevertheless, after more than a year only one research journalism project was completed, namely, "Up There Down", which reached more than $100 \%$ of the targeted amount. Those responsible for this platform indicated that there was no interest, nor a sufficiently large offer by journalists, while from the side of the lenders there was a good response, given that the only existing project even surpassed its overall funding requested. These results indicate that the higher education system is to train journalists with low-level entrepreneurial capacity.

The modus operandi of this platform is similar to other sites in several countries, mostly inspired by the North American platform Spotus.com. Journalists have an idea for a paper, stakeholders contribute a minimum of one and a half euro. The total amount of financing is defined by the journalist, but a private individual or entity may not contribute more than $20 \%$ of application and payment is made through the traditional electronic payment system, leaving the management company's platform Edge Innovation, 15\% of the amount raised.

To subscribe to the platform the journalist must have a professional certification. After this verification, the journalist is free to propose and accept funding for any topic. Also, the publishing process is fully controlled by the writer. After the publication, the texts are two or three months with limited access becoming then freely accessible.

The aim of the project was, according to their leaders, to have a social impact, finding solutions for unemployed journalists or freelancers and even the possibility of developing more informal employment. On the other hand, the possibility was open for journalists to propose controversial projects that had no place in other traditional media.

The initial project consist of three phases but it was accomplished in the second phase and did not get into the third phase. Phase two intends to internationalize the project through the figure of a translator, in order to translate the work into other languages, thus enabling them to be 
available in other countries and, in a third phase, intended to create a figure of "editor in chief". Despite the weak adherence to ongoing, I Fund News is still open and available for use.

The small size of the Portuguese market demanding for crowdfunding was referred in every interview and primary and secondary documentary sources. These results indicate that the higher education system is to train journalists with low entrepreneurial skills as well as internationalization and culture.

Several authors, particularly Mollick (2014) and Agrawal et al. (2013), studied the reasons of successes and failures of projects and determinants. However, none of them can be specifically applied to the case of I Fund News; this platform failed even before it had enough projects. Also, Pereira, Moura, Masanet, Taddeo \& Tirocchi (2018) confirm "nowadays one would expect teens to also be regular producers of media contents and engaged participants in public digital and online spaces. That is not the Portuguese case" (p. 101).

In order to analyze the reasons for the failure of the I fund news platform, we analyzed the importance of the entrepreneurial skills of journalists from its degree at the university level. So, we analyzed the curricular program of all Communication Sciences (CS)/Journalism degrees at bachelor-master and doctoral degrees in general and in journalism in particular, that actually exist in Portugal. A detailed analysis of these current plans and curricula in all Portuguese Universities and Polytechnics allowed us to conclude that, presently, there is a complete absence of the course of entrepreneurship in all bachelors and master's degree in Journalism and CS. Occasionally, some aspects of this course are addressed, albeit incipient and not in a consistent way. This aspect seems to indicate a gap in the education of journalists in Portugal, though that does not relate specifically to the scientific component of the journalist which usually turns out to be a gap of a very important soft skill faced by most current journalists, who complete their university education and that ultimately cannot be integrated into the labour market as dependent workers due the high unemployment rate. Therefore, in order to stimulate the journalist's entrepreneurial character in times of crisis like the present, it is recommended to include this course in their curricula. 
The analysis considered the curricula of undergraduate and master's courses in Communication Sciences (CS) and Journalism taught at different educational institutions, both public and private, in Portugal (shown in Table 1), based on actualized information and data from A3ES (Portuguese Agency for Accreditation Courses/ Degrees in Portugal, (Agência de avaliação e Acreditação no Ensino Superior em Portugal-A3ES, 2015); data from degrees legislation of curricular plans from Diário da República (2015); Portuguese Ministry of Education (Ministério da Educação e Ciência-MCTES, 2018) and all the universities sites referred (2015). With regard to bachelor's degree, in the six existing degrees, only four of them (around $3 / 4$ of the sample) have courses (UC) of economics, which on average account for only an introductory course with about 5 European Credit Transfer System (ECTS). With regard to the master's degree, there is a complete absence of courses in Economics, Entrepreneurship or any other courses of these scientific areas, both in public and private universities. With respect to doctoral degrees, the situation is not very different from master's degrees. Thus, only one private university in Portugal (PT), the Lusofona University of Porto (ULP), has a degree of Social Economy and Development that addresses beyond all thoroughly investigated aspects. The assessment of the course was dependent on the achievement by students of a paper with peer review and indexing in SCOPUS. The almost complete absence of UCs of Economics/ Management area (if included in the latter entrepreneurship), the degrees taught by the Portuguese Higher Education Universities and Polytechnics (HEUP) is explained on the one hand, because in most institutions those same degrees that are taught are in the Faculties of Humanities where the perception of the importance of entrepreneurship and the economy still maintain low level at the present.

The evidence of all the experts consulted by primary and secondary sources, agreeing with the small size of the Portuguese market in the search for crowdfunding, suggests that its development can only be achieved through internationalization (i.e., selecting thematic looking for research journalism at a transnational level). 


\section{TABLE 1}

PRESENCE OF THE SCIENTIFIC COURSES OF ECONOMICS / MANAGEMENT /

ENTREPRENEURSHIP IN THE CURRICULUM PLAN OF THE

Higher EDUCATION UNIVERSITIES AND POLYTECHNICS IN PORTUGAL

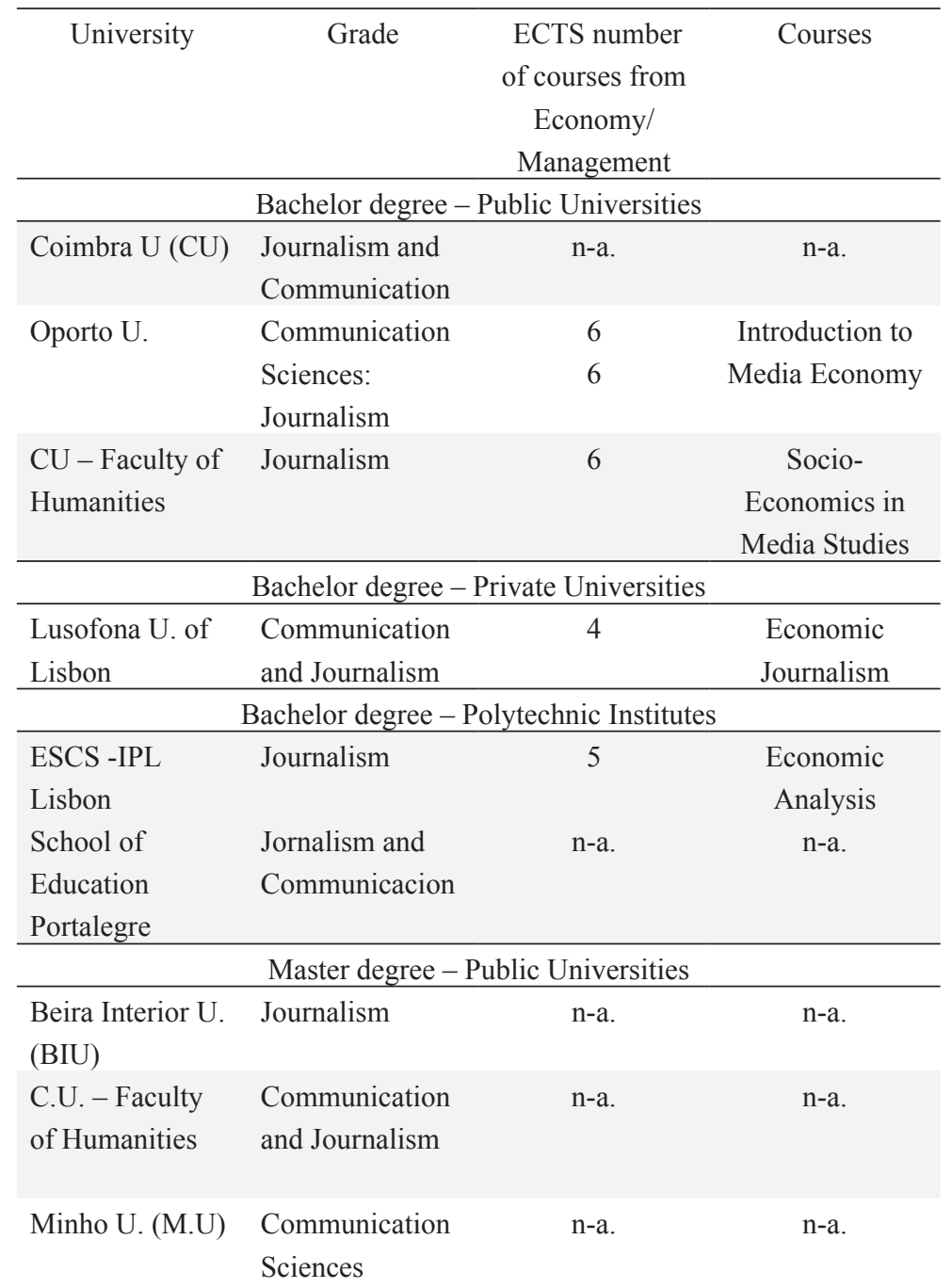




\begin{tabular}{|c|c|c|c|}
\hline University & Grade & $\begin{array}{c}\text { ECTS number } \\
\text { of courses from } \\
\text { Economy/ } \\
\text { Management }\end{array}$ & Courses \\
\hline $\begin{array}{l}\text { U. Nova Lisbon } \\
\text { - FSHS }\end{array}$ & Journalism & $\mathrm{n}-\mathrm{a}$. & n-a. \\
\hline \multicolumn{4}{|c|}{ Master degree - Private Universities } \\
\hline $\begin{array}{l}\text { Lusófona U. of } \\
\text { Lisbon (ULHT) }\end{array}$ & $\begin{array}{l}\text { Journalism, } \\
\text { Politics and } \\
\text { Cont. History }\end{array}$ & n-a. & n-a. \\
\hline $\begin{array}{l}\text { Católica U. - } \\
\text { Braga }\end{array}$ & $\begin{array}{l}\text { Media and } \\
\text { Journalism }\end{array}$ & n-a. & n-a. \\
\hline \multicolumn{4}{|c|}{ Master Degree - Polytechnic Higher Education Public } \\
\hline ESCS (Lisbon) & Journalism & n-a. & n-a. \\
\hline $\begin{array}{l}\text { Sch. Edu. } \\
\text { Portalegre }\end{array}$ & $\begin{array}{l}\text { Journalism, } \\
\text { Com. Culture }\end{array}$ & $\mathrm{n}-\mathrm{a}$. & n-a. \\
\hline \multicolumn{4}{|c|}{ Doctoral degree - Public / Private Universities } \\
\hline Catolica U. - & optional & 6 -optional & $\begin{array}{c}\text { Opt. Economic } \\
\text { of Culture }\end{array}$ \\
\hline $\begin{array}{l}\text { U. Lusófona } \\
\text { Lisbon (ULHT) }\end{array}$ & $\begin{array}{l}\text { Communication } \\
\text { Science }\end{array}$ & n-a. & n-a. \\
\hline $\begin{array}{l}\text { ULHT/ISCTE } \\
\text { - IUL/UBI/U. } \\
\text { Minho }\end{array}$ & $\begin{array}{l}\text { Com St: Tech, } \\
\text { Culture }\end{array}$ & n-a. & n-a. \\
\hline $\begin{array}{l}\text { Lusófona U. } \\
\text { Porto (ULP) }\end{array}$ & $\begin{array}{l}\text { Communication } \\
\text { for Development }\end{array}$ & 7.5 & $\begin{array}{c}\text { Social } \\
\text { Economics and } \\
\text { Dev }\end{array}$ \\
\hline U.Coimbra - & $\begin{array}{l}\text { Communication } \\
\text { Science }\end{array}$ & n-a. & n-a. \\
\hline Lisbon U. - & $\begin{array}{l}\text { Culture Sc. - } \\
\text { Com and Culture }\end{array}$ & $\begin{array}{l}\text { n-a. (with } \\
\text { optional } \\
\text { seminar) }\end{array}$ & $\mathrm{n}-\mathrm{a}$. \\
\hline Lisbon U. - & $\begin{array}{l}\text { Voice, Language } \\
\text { and Com. }\end{array}$ & $\begin{array}{l}\text { (not available } \\
\text { information) }\end{array}$ & $\begin{array}{l}\text { not available } \\
\text { information) }\end{array}$ \\
\hline UTAD & $\begin{array}{l}\text { Corporate Com } \\
\text { Direction }\end{array}$ & $\mathrm{n}-\mathrm{a}$. & n-a. \\
\hline
\end{tabular}




\begin{tabular}{|c|c|c|c|}
\hline University & Grade & $\begin{array}{c}\text { ECTS number } \\
\text { of courses from } \\
\text { Economy/ } \\
\text { Management }\end{array}$ & Courses \\
\hline Algarve U. - & $\begin{array}{l}\text { Communication, } \\
\text { Culture and Arts }\end{array}$ & n-a. & n-a. \\
\hline Minho U. & $\begin{array}{l}\text { Communication } \\
\text { Science }\end{array}$ & n-a. & n-a. \\
\hline $\begin{array}{l}\text { Porto U. / Aveiro } \\
\text { U. }\end{array}$ & $\begin{array}{l}\text { Information and } \\
\text { Com. in Digital } \\
\text { Platforms }\end{array}$ & n-a. & n-a. \\
\hline U. Nova Lisbon & $\begin{array}{l}\text { Communication } \\
\text { Science }\end{array}$ & n-a. & $\begin{array}{c}1 \text { free optional } \\
\text { (10 ECTS) }\end{array}$ \\
\hline $\begin{array}{l}\text { ISCTE - I.U. } \\
\text { Lisbon }\end{array}$ & $\begin{array}{l}\text { Communication } \\
\text { Science }\end{array}$ & $\mathrm{n}-\mathrm{a}$. & n-a. \\
\hline $\begin{array}{l}\text { Beira Interior U. } \\
\text { (BIU) }\end{array}$ & $\begin{array}{l}\text { Communication } \\
\text { Science }\end{array}$ & n-a. & n-a. \\
\hline
\end{tabular}

Note: n-a. not availabe.

Source: A3ES, 2015; Portuguese Ministry of Education (2015); Universities of Portugal, (2015).

\section{CONCLUSION}

The economy of crowdfunding highly suggests that it could be as it is in many countries, an alternative to traditional financing models for entrepreneurs or companies who intend to carry out a particular project, product or service. In the case of the research journalism, several successful platforms have proven to be an alternative for many professionals with the necessary skills to carry out investigative journalism and have the support of willing lenders to pay for stories that have no place in the traditional media. This model has even given rise to new forms of the profession, where the journalist has the support of users, both in relation to the proposed research topics, with regard to the monitoring on the ground and suggestions that can go being given 
throughout the work. Funders become contributors not only for funds but also for ideas in a way that ends up joining the crowdsourcing element, revealing a collective intelligence in favour of journalism.

Besides the crowdfunding projects, there are certain other factors that need to be addressed thoroughly which are the hot discussion in the current scenario of journalism in Portugal.

However, the real situation demonstrates practically no impact of crowdfunding as a way to successfully fund investigative journalism in Portugal. The only national platform exclusively dedicated to receiving journalistic research projects was only successful in one investigative project, which was due, not to the weak demand from readers, but mainly to the lack of entrepreneurial skills of journalists. Therefore, we suggest that higher education in Portugal teach entrepreneurship courses in order to train future professionals in the field, both at initial training level and post-graduate.

The results of the analysis of the curricula in all degrees in all academic levels in Portugal allowed us to confirm that except for a doctoral degree in Studies in Communication for Development at Lusófona University of Porto (ULP), there is not an objective approach in entrepreneurship or economics sciences or international culture at all the degrees and levels of education in Portugal. It is therefore suggested, a greater and better integration of these courses within other existing higher education institutions, namely with the Faculties of Economics and Management. We suggest the inclusion of applied and general scientific areas in economics in general and Management/ Entrepreneurship in particular in order to train future professionals and researchers from Communication Sciences and to allow them the professional development appropriate to a world in constant evolution.

We strongly recommend future and further analysis that should also investigate other reasons for the failure of this journalism platform, in order to understand what paths follow the experienced journalists, as well as the attitude of the Portuguese financiers before the possibility of contributing for research reporting projects proposed by journalists or by the public according to their preferences or needs. 


\section{Bibliographic references}

Agência de avaliação e Acreditação no Ensino Superior em PortugalA3ES. (2015). Avaliação de Cursos em Funcionamento. Retrieved from http://www.a3es.pt/

Agrawal, A., Catalini, C. \& Goldfarb, A. (2011). The Geography of Crowdfunding. NBER Working Paper, 16820. Retrieved from http://www.nber.org/papers/w16820

Agrawal, A., Catalini, C. \& Goldfarb, A. (2013). Some simple economics of crowdfunding. NBER Working Paper, 19133. DOI: https:// doi.org/10.3386/w19133

Aitamurto, T. (2011). The impact of crowdfunding in journalism. Case study of Spot.us, a platform for community-funded reporting. Journalism Practice, 5(4). DOI: https://doi.org/10.1080/17512786.2010 .551018

Albarran, A. B. (2016). The media economy. New York: Routledge.

Anderson, C. W., Bell, E. \& Shirky, C. (2015). Post-Industrial Journalism: Adapting to the Present. Geopolitics, History \& International Relations, 7(2).

Anglin, A. H., Short, J. C., Drover, W., Stevenson, R. M., McKenny, A. F. \& Allison, T. H. (2018). The power of positivity? The influence of positive psychological capital language on crowdfunding performance. Journal of Business Venturing, 33(4), 470-492. DOI: https:// doi.org/10.1016/j.jbusvent.2018.03.003

Barabas, R. L. (2012). Crowdfunding: Trends and Developments Impacting Entertainment Entrepreneurs [Blog entry]. The Entertainment, Arts and Sports Law Blog. Retrieved from http://nysbar.com/ blogs/EASL/2012/02/crowdfunding_trends_and_develo.html

Belleflamme, P., Lambert, T. \& Schwienbacher, A. (2014). Crowdfunding: Tapping the Right Crowd. Journal of Business Venturing, 29(5), 585-609. DOI: https://doi.org/10.1016/j.jbusvent.2013.07.003

Bogost, I. (2012). Kickstarter: Crowdfunding Platform or Reality Show? Fast Company. Retrieved from http://www.fastcompany. com/1843007/kickstarter-crowdfunding-platform-or-reality-show

Carvajal, M., García-Avilés, J. A. \& González, J. L. (2012). Crowdfunding and non-profit media. The emergence of new models for public interest journalism. Journalism Practice [Special Issue: The 
Future of Journalism: Developments and Debates], 6(5-6). DOI: https://doi.org/10.1080/17512786.2012.667267

Coelho, P., Silva, M. T. (2018). O lucro social e financeiro do jornalismo de investigação. Media \& Jornalismo, 18(32), 73-94. DOI: https://doi.org/10.14195/2183-5462_32_6

De Buysere, K., Gajda, O., Klevelaman, R. \& Marom, D. (2012). A Framework for European Crowdfunding. Retrieved from https:// d21 buns $5 \mathrm{ku} 92$ am.cloudfront.net/26522/documents/179301351284179-FRAMEWORK_EU_CROWDFUNDING.pdf

Du, S., Yalcinkaya, G., Bstieler, L. (2016). Sustainability, social media driven open innovation, and new product development performance. Journal of Product Innovation Management, 33, 55-71. DOI: https:// doi.org/10.1111/jpim.12334

Freitas, A., Silva, A. I., \& Amante, S. (2017). Re[a]presentações do jornalismo de investigação na voz dos profissionais de comunicação. In Atas $10^{\circ}$ Congresso da SOPCOM. Ciências da Comunicação: 20 anos a investigar em Portugal (pp. 129-129). Retrieved from http:// hdl.handle.net/10400.19/5586

Gerber, E. M., Hui, J. S. \& Kuo, P. Y. (2012). Crowdfunding: Why People Are Motivated to Post and Fund Projects on Crowdfunding Platforms [Working paper Northwestern University Creative Action Lab]. Retrieved from http://distworkshop.files.wordpress. com/2012/01/dist2012_submission_11.pdf

Gómez-Rodríguez, G. \& Gallo-Estrada, M. C. (2016). El proceso de transición de las revistas académicas: de impreso a digital. Paakat: Revista de Tecnología y Sociedad, 6(10). Recuperado de http:// www.udgvirtual.udg.mx/paakat/index.php/paakat/article/view/265/ html

Gómez-Rodríguez, G., Méndez-Pupo, Y. \& Cortés-Lozano, M. (2015). Cobertura de la violencia ante la contención informativa: el retorno del PRI y sus viejas prácticas de control periodístico en la Zona Metropolitana de Guadalajara. In C. del Palacio (Coord.) Violencia y periodismo regional en México (pp. 203-524). Ciudad de México: Editorial Juan Pablos.

Gómez-Rodríguez, G., Morrell, A. E., \& Gallo-Estrada, C. (2017). A 30 años de Comunicación y Sociedad: cambios y permanencias en el campo académico de la comunicación. Comunicación y Sociedad, (30), 17-44. DOI: https://doi.org/10.32870/cys.v0i30.6838 
Howe, J. (2006). The Rise of Crowdsourcing. Wired, 10(1), 34-55. Retrieved from https://www.wired.com/2006/06/crowds/

Howe, J. (2008). Crowdsourcing. Why the power of the crowd is driving future of business. New York: Macmillan.

Kleemann, F., Voss, G. \& Rieder, K. M. (2008). Un(der)paid Innovators: The Commercial Utilization of Consumer Work through Crowdsourcing. Science Technology and Innovation Studies, 4, 5-26.

Lambert, T. \& Schwienbacher, A. (2010). An Empirical Analysis of Crowdfunding. Prepared for the workshop Economics France. Retrieved from http://www.crowdsourcing.org/document/an-empirical-analysis-of-crowdfunding-/2458

Lawton K., Marom, D. (2010). The Crowdfunding Revolution: Social Networking Meets Venture Financing. Retrieved from www. thecrowdfundingrevolution.com

Lewis, S. C. \& Westlund, O. (2015). Big data and journalism: Epistemology, expertise, economics, and ethics. Digital Journalism, 3(3), 447-466. DOI: https://doi.org/10.1080/21670811.2014.976418

Martín Serrano, M. (2019). Cuándo y cómo se hizo científica la Teoría de la Comunicación. Comunicación y Sociedad, e7477. DOI: https:// doi.org/10.32870/cys.v2019i0.7477

Ministério da Educação e Ciência-MCTES. (2018). Acesso Ensino Superior http://www.dges.mctes.pt/DGES/pt/Estudantes/Acesso/

Mollick, E. (2014). The dynamics of crowdfunding: Determinants of Success and Failure. An Exploratory Study. Journal of Business Venturing, 29(1), 1-16. DOI: https://doi.org/10.1016/j.jbusvent.2013.06.005

Parhankangas, A. \& Renko, M. (2017). Linguistic style and crowdfunding success among social and commercial entrepreneurs. Journal of Business Venturing, 32(2), 215-236. DOI: https://doi.org/10.1016/j. jbusvent.2016.11.001

Pereira, S., Moura, P., Masanet, M. J., Taddeo, G. \& Tirocchi, S. (2018). Media uses and production practices: case study with teens from Portugal, Spain and Italy. Comunicación y Sociedad, 33, 89-114. DOI: https://doi.org/10.32870/cys.v0i33.7091 
Rivera, B. E. (2012). Crowdfunding: La eclosión de la financiación colectiva, un cambio tecnológico, social y económico. Barcelona: Microtemas.

Schwienbacher, A., Larralde, B. (2010). Crowdfunding of small entrepreneurial ventures. In D. J. Cumming (Ed.), The Oxford Handbook of Entrepreneurial Finance. DOI: https://dx.doi.org/10.2139/ ssrn. 1699183

Steinberg, S., DeMaria, R. (2012). The Crowdfunding Bible: How to Raise Money for Any Startup, Video Game or Project. Retrieved from http://www.asmallbusinessexpert.com/ 